Available Online at ESci Journals

Journal of Plant Breeding and Genetics

ISSN: 2305-297X (Online), 2308-121X (Print)

http://www.escijournals.net/JPBG

\title{
INDIGENOUS KNOWLEDGE ON CULTIVATION AND CONSUMPTION OF ENSET (ENSET VENTRICOSUM) IN KERCHA DISTRICT; WEST GUJI ZONE, OROMIA REGION OF ETHIOPIA
}

\author{
aItefa Degefa*, bessay Dawit \\ a Genetics program, Biology department, college of natural and computational sciences, Bule Hora University, Ethiopia. \\ b Department of Biology, Bule Hora University, Ethiopia.
}

\begin{abstract}
A B S T R A C T
Enset (Enset ventricosum) is a perennial herbaceous root crop with long broad leaves and bulky pseudo-stem. It is one of the important food secure plant due to drought resisting property. This research was conducted with the objective of assessing indigenous knowledge of enset farming and its consumption experienced in Kercha district, west Guji zone, and Oromia region of Ethiopia. Four kebeles were selected purposively based on the enset vegetation coverage and 80 informants were selected by stratified sampling method. Data was collected using open questionnaires, interview and field observation and it was analyzed using SPSS software and Microsoft Excel. The present result showed that 21 enset varieties have been identified and not all of them were preferred for cultivation. Instead, farmers select and maintain these local varieties that best meet their needs using their indigenous knowledge. Accordingly, 25\% of them based on resistance to pest and disease, and $22.5 \%$ of them based on maturation period are the most criteria the farmers would always consider. Although most farmers cultivate enset in the home garden, the mode cultivation was varying from highland to lowland. For example $82, .75 \%$ of respondents use mono-cropping and $17.25 \%$ of them use the intercropping system in the highland area while, in Midland areas, $86.25 \%$ of respondents use intercropping and $13.75 \%$ of them use mono-cropping mode of cultivation. However, it is used for many purposes, the present result showed that enset is cultivated mainly for food as $63.75 \%$ of respondents' feedback in the district where the corm and the pseudo-stem are the most important sources of food. The types of food from these parts are locally known 'Kocho or Warqe', 'Bulla or Haruro' and 'Amicho or Ham'o'. From these, the major products prepared are locally known as are 'quncisa,' 'wodhamo', 'hocoqo' and 'qixa'. Hence, despite the enset has the potential for food security and income generation which is known by indigenous people, it has been cultivating by the traditional farming system. So, further investigation is required to scale up the knowledge of farmers to the modern farming system.
\end{abstract}

Keywords: Enset Farming, Indigenous Knowledge, Kocho, Bulla.

\section{INTRODUCTION}

Many crop plants that have been under cultivation and contributing to the livelihoods of local communities which scarcely known are primarily grown in subsistence farming systems in many developing countries like Ethiopia. They substantially contribute to food and nutrition security of small-scale farming households (Olango et al., 2014). From these crops,

* Corresponding Author:

Email: ittafaadaggafaa@gmail.com

Tel: 0917135801

(C) 2018 ESci Journals Publishing. All rights reserved. enset (E. ventricosum) commonly known as a false banana or Abyssinian banana (Assefa and Fitamo, 2016) is adapted to a wide range of altitudes from 1200 to 3100 meters at sea level. The enset is a crop that tolerates prolonged drought periods and the plant has high yielding potential compared to annual crops (Mohammed et al., 2013).

The enset based farming system in Ethiopia is a major agricultural system that serves at least one-fifth of country's population and the total area covered with enset crop has more than quadrupled and approximately 321,362 ha (Yemataw et al., 2017). Because enset is the 
main source of food in the densely populated areas of the central and southwestern parts of the country. It is a high-value crop in the southern region and some parts of Oromia (SARI, 2014). The crop has multipurpose like for food, for cultural application, cash product, traditional medicine, sources of fuelwood, construction materials and livestock feeding ((Shumbulo et al., 2012; Zeberga et al., 2014).

The diversities of enset species occurring in the farming system resulted from evolutionary processes over the centuries influenced by environmental variability and domestication processes guided by native cultures, knowledge and traditions (Olango et al., 2014). Indigenous knowledge of enset farming and its management practices in some parts of southern region (Wolayita, Sidama, Shekicho, Gamo, Gurage and Gedo) and in some parts of Oromia region (Western Shewa, Ilubabor and Wollega) were documented and deployed (Assefa and Fitamo, 2016; Garedew et al., 2017). The local knowledge of farmers' and farming practices of agro-biodiversity is a crucial starting point for improving farming systems. Although the farmers have an amazing knowledge for enset farming system like propagation, transplanting, intercropping, harvesting, processing, protection from pests and diseases (Garedew et al., 2017), few studies have been conducted in west Guji zone at kercha district and the indigenous knowledge of enset farming and its farming practices were not well known by the scholars in this area. Therefore, the general objective of this study was to explore the indigenous knowledge of enset farming and its management practices experienced in the kercha community.

\section{MATERIALS AND METHODS}

Description of Study Area: This study was conducted in southern Ethiopia, Kercha district of the west Guji zone. Geographically, it lies between 38021' E to 39054' E latitude and $5027^{\prime} \mathrm{N}$ to $5051^{\prime} \mathrm{N}$ longitude. It is located at a distance of $461 \mathrm{~km}$ from the Addis Ababa, the capital city of Ethiopia. Kercha district is bordered by Melka Soda, Bule Hora, Gedeb (SNNPR) and Birbissa Kojowa districts where its annual temperature range is $15^{\circ} \mathrm{C}$ $25^{\circ} \mathrm{C}$ and the rainfall range from $930-1500 \mathrm{~mm}$. The area has three agro-ecological regions, Highland (4.3\%), Midland (95\%) and lowland (0.2\%) which are largely covered by coffee and enset vegetation. The soil type of the area is characterized by silt, clay, and sandy, but largely characterized by $98 \%$ silt soil (From Kercha Woreda administrative offices, 2018).

Study Design: A cross-sectional study was employed in four selected kebeles from 23 kebeles based on the enset cultivation potential. The selected kebeles were "L/Qarcaa", "G/Jaldoo", "L/Irbaa", and "E/Abbayyii", to assess the indigenous knowledge of enset farming and its management practices by enset cultivators of Kercha communities.

Sampling Techniques: The survey was conducted in four kebeles purposively based on the availability of enset vegetation. Top twenty households were chosen by their potential cultivation of enset crop from each Kebele by the guidance of Agricultural Officers or Development Agents (DA). Total of 80 households were chosen for an interview and considered as the overall sample size for the study. During this, both sexes and elders were included in the sample to get good traditional knowledge.

Data Collection: In April and May 2018, data was collected through oral interview and field observations. Language translator was involved in translating the English language to Afan Oromo language for the respondents. Types of data recorded were vernacular names of enset, cultivation system, harvesting method and constraints like diseases and pests and its management in their area.

Data Analysis: The collected data was analyzed using SPSS version 20.0 software and Microsoft excels. The analyzed data was interpreted using descriptive statistics like frequency, percentages, tables and graphs.

\section{RESULT AND DISCUSSION}

Demographic Characteristics of the informants: As shown in table 1 , from the total informants, $22.25 \%$ of the informants were the age of between 18-25 years old, while $30 \%$ were age between $26-35$ years old, $41.25 \%$ and $6.25 \%$ of the informants were between the age of 36-50 and above 50 years old respectively. Most of the respondents were men (60\%) and $40 \%$ of them were women which indicating that mostly one who involved in farming practice were men. Data concerning to educational status of the informants showed that $26.25 \%$ of them were no schooling, $47.5 \%$ are an elementary school, $13.75 \%$ and $12.5 \%$ of them were senior secondary school and completed secondary school respectively. 
Table 1. Demographic characteristics of respondents in each kebele.

\begin{tabular}{|c|c|c|c|c|c|c|c|}
\hline Kebele & Age & Sex & & & & Total & Agroecology \\
\hline & & Male & Female & Total & $\%$ & & \\
\hline \multirow[t]{4}{*}{ L/Qarcaa } & $18-25$ & 1 & 2 & 3 & 3.75 & 20 & W/Dega \\
\hline & $26-35$ & 4 & - & 4 & 5 & & \\
\hline & $36-50$ & 5 & 5 & 10 & 12.5 & & \\
\hline & $>50$ & 2 & 1 & 3 & 3.75 & & \\
\hline \multirow[t]{4}{*}{ G/Jaldoo } & $18-25$ & 3 & 2 & 5 & 6.25 & 20 & W/Dega \\
\hline & $26-35$ & 2 & 2 & 4 & 5 & & \\
\hline & $36-50$ & 4 & 4 & 8 & 10 & & \\
\hline & $>50$ & 3 & - & 3 & 3.75 & & \\
\hline \multirow[t]{4}{*}{ L/Irbaa } & $18-25$ & 2 & 2 & 4 & 5 & 20 & Dega \\
\hline & $26-35$ & 3 & 4 & 7 & 8.75 & & \\
\hline & $36-50$ & 5 & 1 & 6 & 7.5 & & \\
\hline & $>50$ & 2 & 1 & 3 & 3.75 & & \\
\hline \multirow{5}{*}{ E/Abbayyii } & $18-25$ & 2 & 1 & 3 & 3.75 & 20 & Dega \\
\hline & $26-35$ & 6 & 1 & 7 & 8.75 & & \\
\hline & $36-50$ & 2 & 4 & 6 & 7.5 & & \\
\hline & $>50$ & 2 & 2 & 4 & 5 & & \\
\hline & Total & 48 & 32 & 80 & 100 & 80 & \\
\hline
\end{tabular}

Selection of Enset (E. ventricosum) varieties: Although there were abundance and distribution of enset varieties (landraces) in the study area, the local farmers were trying to adapt their traditional variety selection methods that they cultivate and propagate on their farmland or home garden based on productivity, adaptability, resistivity and cultural value of enset from generation to generation as shown on the figure 1.

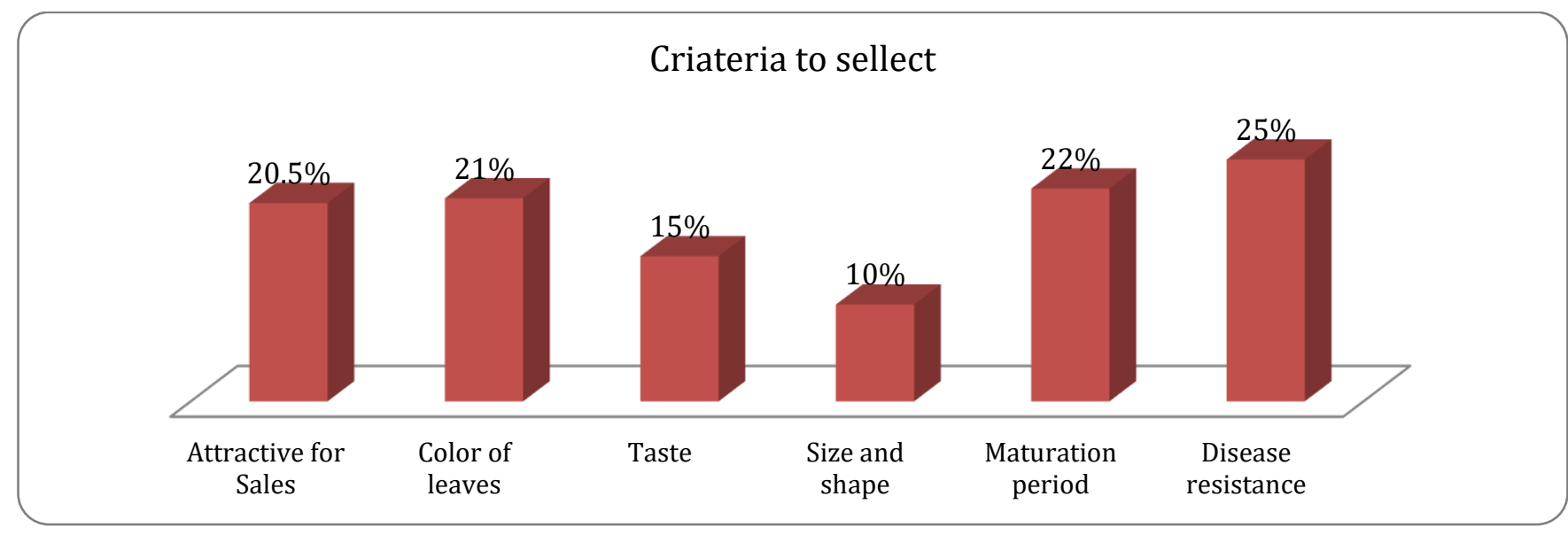

Figure 1. Farmers' Criteria to select the varieties of enset crops.

The main criteria used to select for farming enset variety by local farmers was based on the disease resistance accounted for $25 \%$ of respondents feedback followed by maturation period $(22.5 \%)$. The size and shape of the plant got less attention in selection as $10 \%$ of the respondents' feedback. Using the above criteria of indigenous knowledge of farmers, for instance, 21 enset varieties were known in the Kercha Districts. Based on production, maturation time and size of enset, the indigenous farmers classified enset varieties traditionally as a category of male and female types. Among these enset varieties, the local farmers used to select the most common male diseases resistance varieties of enset like 'Gantichaa', 'Bobbeyyaa' and 'Qorqooroo'. However, the female varieties include 'Niffo', 'Shaaynaa' and 'Toraamee'. These varieties are listed in table 2 according to their local naming system. 


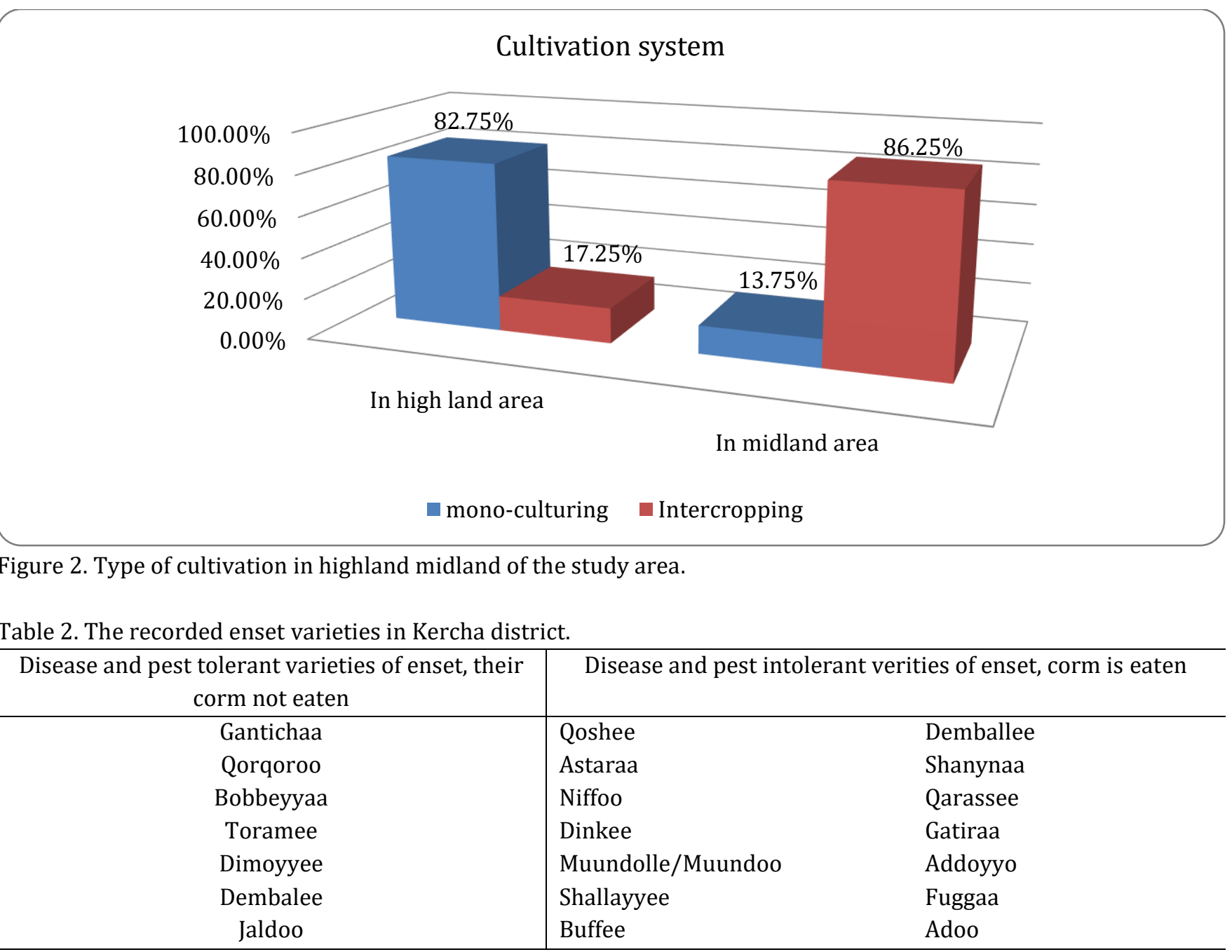

Cultivation of Enset: Even though the distribution and abundance of enset vary in terms of cultivars and productivities from kebele to kebele of the study sites, almost all of the farmers cultivate it for their staple food in addition to grains. The result is in line with the study of (Garedew et al., 2017) who said enset is cultivated as a food and fibre crop only in Ethiopia, particularly in the southern, southwestern and western parts of the country.

Farmers grow a different type of enset varieties in a different manner of associations. As indicated below figure 2, most of the farmers highly practised monoculturing $(82.75 \%)$ followed by intercropping (17.25\%) mode of cultivation in the highland area. This indicating that they believe the mono-culturing due to some of the enset varieties grow better in the absence of shade or any association and if there are other plants around it, it does not give a good yield and its corm and pseudostem may be affected during harvesting of other nearby crops. However, in the midland area inter-cropping (86.25\%) system of culturing is highly practised and followed by mono-culturing (13.75\%) as indicated in (Figure 2). They believe that the enset have important for shading if they cultivated with different root or tuber crops and cereal crops. Additionally, the farmers assumed intercropping enset crops with other grains or tubers were to enhance the fertility of soil due to the remains of these crops in the farmland or home garden and possibly get good product or yield of the crops for the next season production. So, farmers in the study area practised intercropping of enset with maize, cabbage, and bean, different fruits like mango, avocado and coffee. This result was in agreement with the report of Olango et al., (2014) that showed the most common crops intercropping with enset were maize, cabbage, bean and Godare in Wolayita area, Southern Ethiopia. 

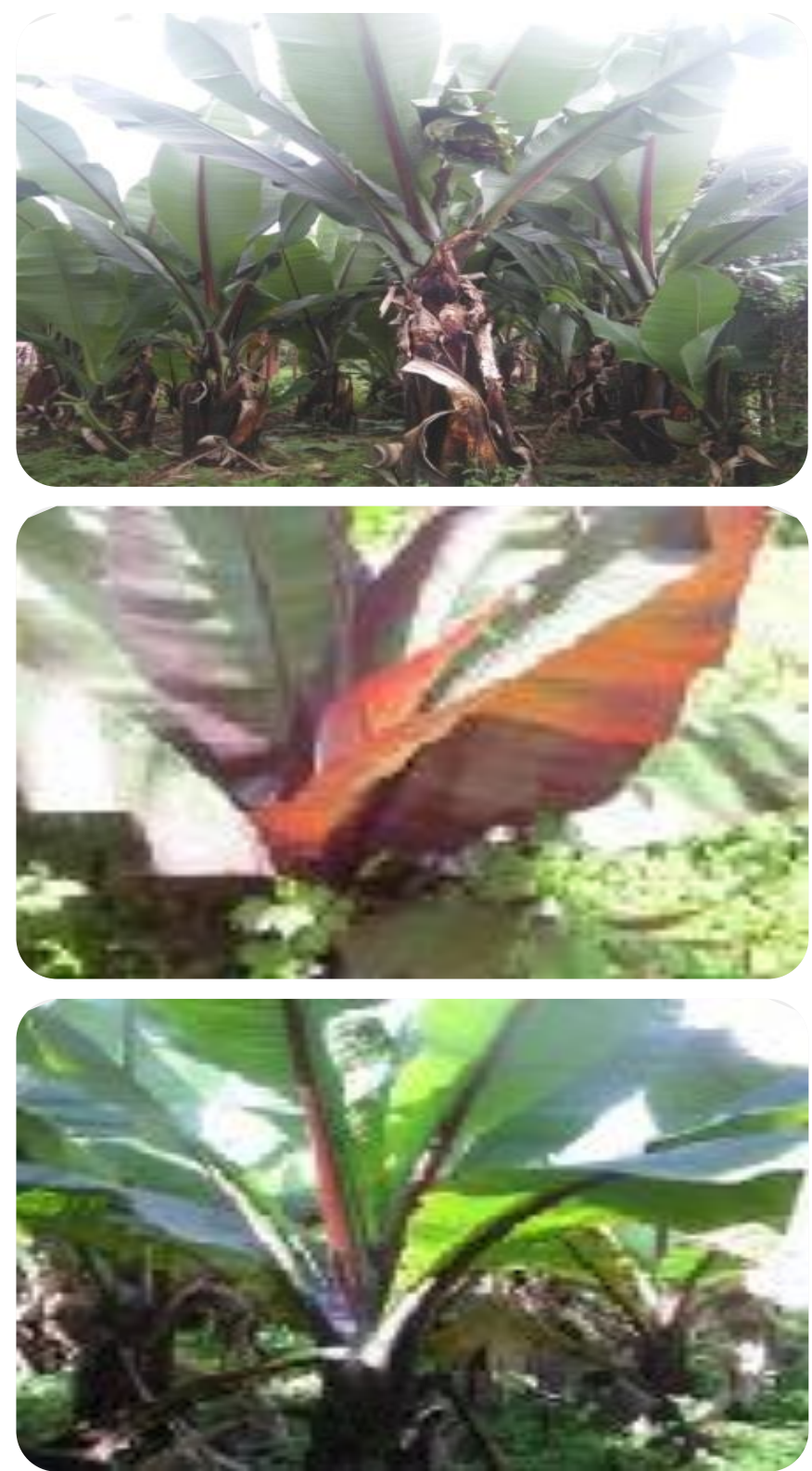

Figure 3. Photo of some enset varieties.

Propagation: Enset is cultivated using most commonly by propagation of vegetative suckers and the method is the traditional way. Propagation is a cultural practice carried out every year from late December to early February using a mixture of landraces. Olango et al. (2014) also reported that the regular propagating of landraces is practised to regulate enset cycle and to maintain on-farm landrace diversity. On average, the farmers propagate 5-10 plants per year before the onset of the rainy season as the report of (Garedew et al., 2017). Enset suckers are produced from underground stems or corms where these mother corm pieces are obtained by
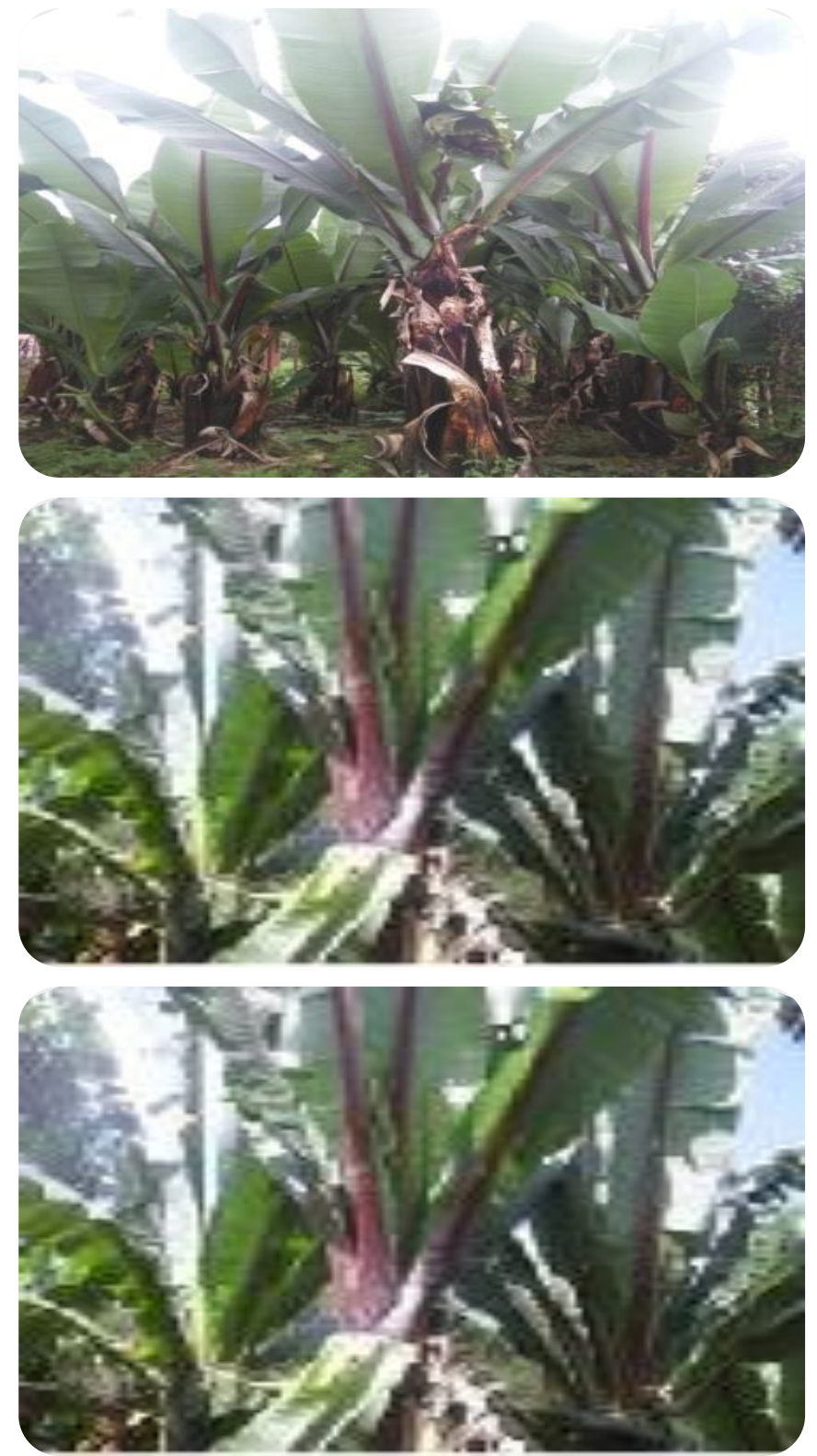

harvesting healthy plants, cutting off the pseudostems, removing the roots, and removing out the centre or apical bud. Once the apical bud is removed then mother corm piece is covered by the soil. These lateral buds form suckers around the periphery of the mother corm piece. Not all farmers get an equal number of suckers from a single mother enset plant. The number of suckers (seedling) obtained from a single mother plant is determined by soil condition, types of clones, size and age of mother plant, amount of rainfall, land preparation and time of planting. After three months, 20 to 200 suckers can be obtained per corm piece. About $63 \%$ of 
respondents replied 2-3 years old age is a good stage for seedling reformation. Inversely, about $29 \%$ and $8 \%$ reported 3-4 years and 4-5 years old age of enset are suitable times for propagation as shown in table 3 .

Transplanting: Farmers do not plant suckers directly in the permanent field once rather they used to transplant enset suckers from one to three times until it gets the permanent field. The multiple suckers, rising from the buried corm (locally known as 'Turichaa') kept underground for one year are separated from the corm and replanted in well-mannered nurseries. Replanted 'Turicha' grow in the nursery for another year after which they named 'Sime'. A successive transplanting produces a new 'Warqicha' (three years old plants). In addition of being used as mother corm for propagation, plants at 'Warqicha' stage may be harvested for consumption, especially in food shortage seasons or are transplanted as the definitive establishment where they will stay until harvesting for processing. This stage is known as the inflorescence stage (locally known as 'Dhala' stage) similar to the report of (Shumbulo et al., 2012) in case of Wolayita zone. Data indicated that more than $75 \%$ of the farmers in the area transplant enset at least twice. Such cultural practice has a double disadvantage in that it extends the time enset require to reach maturity and it causes additional labour and land wastage which would have been used for other purposes.

Table 3. Propagation age and transplanting period of enset.

\begin{tabular}{lcc}
\hline Age of enset for propagation & Frequency & Percent (\%) \\
\hline 2-3 years old & 57 & 71.25 \\
3-4 years old & 23 & 28.75 \\
4-5 years old & 5 & 6.25 \\
\hline Total & 80 & 100 \\
\hline Frequency of transplanting & & \\
\hline One time per year & 8 & 10 \\
Two times per year & 62 & 77.5 \\
Three times per year & 10 & 12.5 \\
\hline Total & 80 & 100 \\
\hline
\end{tabular}

Informants replied that the compost fertilizer and remains of straw are preferable for the cultivation of enset crops to get good products rather than inorganic fertilizers in their farmland. However, they identified various constraints for the production of enset. For example, enset bacterial wilt (local name 'wodho') is the most serious constraint on enset production. The existence of enset bacteria wilt in the field is known by a wilting and yellowish leaf or yellowish leaf as the symptoms of the disease. The farmers correctly knew the principal means of enset bacterial wilt disease transmission from an external source to the farmers' field, from infected to healthy plants via contaminated tools and insects, even if a minority erroneously identified animal dung, and wind transmission. They used to take preventative or disease cultural control measures like sanitary enhancement, uprooting the infected one from the health, planting other plants (mango, avocado, coffee) instead of the infected one, applying fresh manure and sterilizing the processing materials like the report in (Dejene and Yemataw, 2018) Kenbata sTembaro zone. Additionally, some pests that affect the production of enset are a rodent ('kure'), shrew ('tuqa') and rat ('hantuta') when enset cannot be properly managed.

Table 4. Major constraints in enset production.

\begin{tabular}{lcc}
\hline Constraints in enset products & Frequency & Percent (\%) \\
\hline Enset bacterial wilt(wondho) & 51 & 63.75 \\
Dobbalo(Blackening of corm) & 7 & 8.75 \\
Xete & 12 & 15 \\
Pests (shrew, rat, 'Kure') & 10 & 12.5 \\
\hline Total & 80 & 100 \\
\hline
\end{tabular}

Maturity, Harvesting and Storage of Enset: The maturity, harvesting time and storage place were different from place to place and various types of enset in the study area that cultivated by local farmers. Some of the indicators associated with the maturity of enset for harvesting in the study area used by the indigenous farmers are the size of an individual plant, development of the corm (locally known as Ham'o or Amicho) above the ground and formation of inflorescence colour. After checking the maturity, they harvest and store to extend the shelf life of the crops. The farmers store enset products (e.g. Kocho and Bula) by wrapping and covering them on the well-shaded site for a further supply of food. The result is in agreement with Olango et al. (2014).

Processing of Enset for Consumption: Although every part of enset is usable, corm and pseudostem are the most important sources of food. The types of food from these parts are known as 'Kocho or Warqe', 'Bula or Haruro' and 'Amicho or Ham'o', According to the report 
of Chaka Tuffa et al. (2017), amicho or ham'o is boiled corm of young enset plants known for the best quality of corm. Certain clones are selected for their amicho production by the farmers. For example, local variables such as 'Astara' is preferred for amicho purposes by the Kercha people but it is susceptible to diseases.

Here are the steps used by respondents in the area to prepare 'bulla': Scraping the leaf sheath, peduncle, and grated corm into a pulp $\rightarrow$ Squeezing liquid containing a starch from the pulp $\rightarrow$ allowing the resultant starch to concentrate into a white powder and $\rightarrow$ Rehydrating with water. In addition to this, it is considered that the best quality enset food and is obtained mainly from fully matured enset plants and fibre ('Hanxa') is the byproduct of enset that is left after scraping the leaf sheaths. Fibre is used for making ropes, mats, for filtering butter and for filtering undigested matter in ruminant stomach. This finding is in line with the report of (Garedew et al., 2017).

Socio-Cultural Use of Enset: the present finding showed that $63.75 \%$ of respondents said as enset is mostly used for food and $17.5 \%$ of them reported as it used for cash and $8.5 \%$ of them for animal feed. The types of food prepared from the major products known by the local peoples are 'quncisa,' 'wodhamo', 'hocoqo' and 'qixa'. The report of Gebresenbet (2012) also similar to the present finding which said enset are a type of root and tuber crops that used mainly for human food as nonprocessed or processed form for animal feed, traditional medicine, household utilities (dish, bags, ropes, mats and wrapping material), construction materials (to build house and fence), fuel (cooking and heating), cash crop, aesthetic values and fibers.

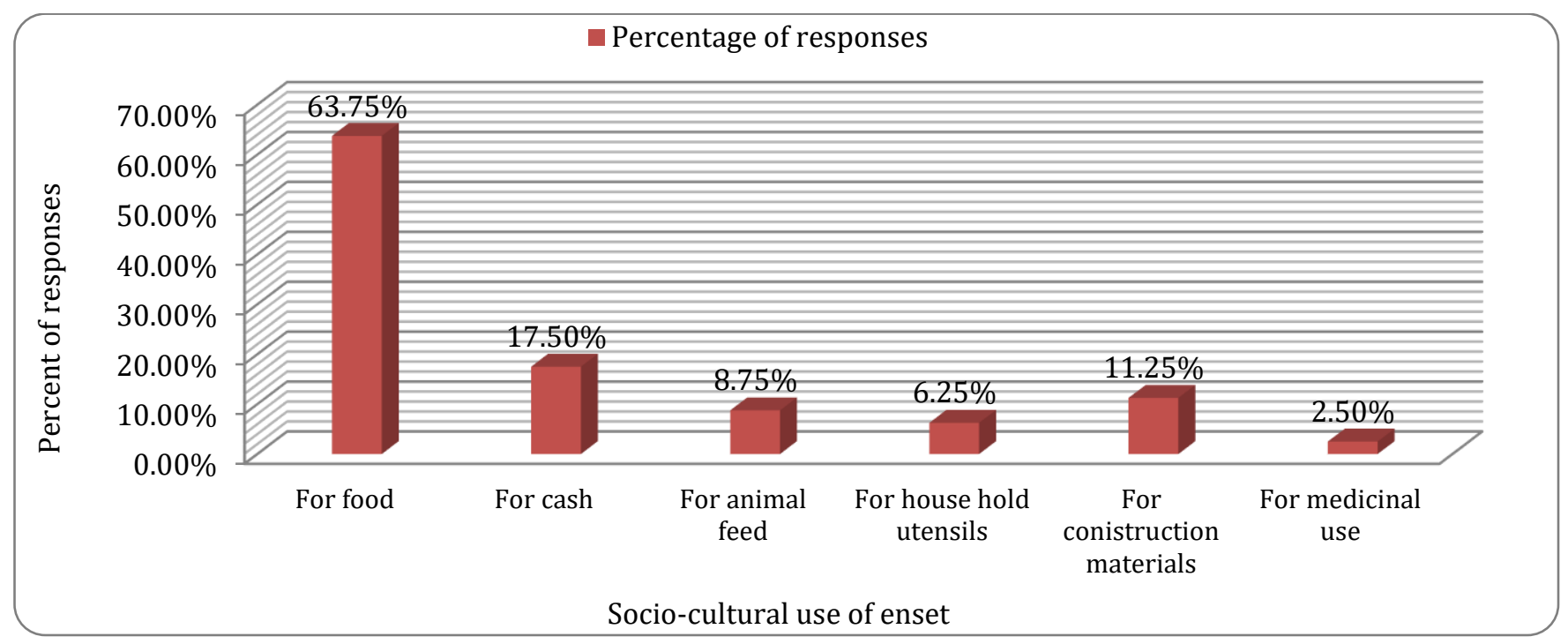

Figure 4. Socio-cultural use of enset.

\section{CONCLUSION}

Based on the present result the researchers concluded that in kercha district, there are different local varieties (landraces) of enset and farmers have good traditional knowledge about the use, cultivation, propagation and management which is still maintained among the local people of the area. The cultivation system was varying from highland to Midland. For example, the percent of mono-cropping in the highland area is $82.75 \%$ and intercropping in the Midland area is $86.25 \%$. Farmers select and maintain these local varieties that best meet their needs using their interest based on criteria of resistance to pest and disease, maturation period, shape, colour, size of leaves. As farmers of the study area depicted, their enset varieties decreased through time due to displacement by other crops such as avocado, coffee, and other vegetables in the area. Moreover, the young generation shows a lack of interest to cultivate and manage enset as elders, the traditional knowledge on the plants might be eliminated in the near future unless proper cultivation and management is made. Taking into account the roles of enset in cultural and traditional using and cultivation system, better attention needs to be given by all concerning bodies to maintain diversities and further farmers should be supported and encouraged to continue transferring their 
indigenous knowledge about enset farming and processing system because it may be the future research area and technology development.

\section{ACKNOWLEDGEMENT}

Bule Hora University and Kercha Woreda Agricultural office are highly acknowledged.

\section{ETHICAL CONSIDERATION}

No data was stolen from others' document. Human, as well as others' right, was not violated. The manuscript was not published elsewhere.

\section{REFERENCES}

Assefa, A.S., Fitamo, D., 2016. Diversity of enset landraces (Ensete ventricosum (Welw) Cheesman) in Aleta Chuko District, Sidama Zone, South Nation Nationality People and Regional State, Ethiopia. Journal of Plant Sciences 4, 1-7.

Chaka Tuffa, A., Kenea Amentae, T., Gebresenbet, G., 2017. Value Chain Analysis of WARQE Food Products in Ethiopia. International Journal of Managing Value and Supply Chains 8, 23-42.

Dejene, T., Yemataw, Z., 2018. Diversity, indigenous knowledge and management of enset diversity on evidence diversity, indigenous knowledge and management of enset diversity on-farm: evidence from Kembata Tembaro zone, Angacha woreda, Ethiopia. International Journal of Current Research 10, 60-66.

Garedew, B., Ayiza, A., Haile, B., Kasaye, H., 2017. Indigenous knowledge of Enset (Ensete ventricosum (Welw.) Cheesman) cultivation and management practice by Shekicho people, Southwest Ethiopia. Journal of Plant Sciences 5, 6.

Gebresenbet, G., 2012. Reduction of Post-harvest Loss in Potato and Enset to Increase Food Supply in
Ethiopia, Workshop on Reduction of Post-harvest Losses and Value Addition in East African Food Value Chains, Nairobi Kenya, pp. 26-28.

Mohammed, B., Martin, G., Laila, M.K., 2013. Nutritive values of the drought tolerant food and fodder crop enset. African Journal of Agricultural Research 8, 2326-2333.

Olango, T., Tesfaye, B., Catellani, M., Pè, M., 2014. Indigenous knowledge, use and on-farm management of enset (Ensete ventricosum (Welw.) Cheesman) diversity in Wolaita, Southern Ethiopia. Journal of Ethnobiology and Ethnomedicine 10, 41.

SARI, 2014. Integrated Management of bacterial wilt of Enset (E. ventricosum (Welw) Cheesman) caused by Xanthomonas campestris vp.musacearum in Ethiopia, Enset Bacterial Wilt, Year Three Report. McKnight Foundation.

Shumbulo, A., Gecho, Y., Tora, M., 2012. Diversity, challenges and potentials of enset (Ensete ventricosum) production: in case of Offa Woreda, Wolaita Zone, Southern Ethiopia. Food Science and Quality Management 7, 24-31.

Yemataw, Z., Chala, A., Ambachew, D., Studholme, D., Grant, M., Tesfaye, K., 2017. Morphological Variation and Inter-Relationships of Quantitative Traits in Enset (Ensete ventricosum (welw.) Cheesman) Germplasm from South and SouthWestern Ethiopia. Plants 6, 56.

Zeberga, A., Yemataw, Z., Sinebo, W., Ambachew, D., Musemil, S., 2014. On Farm Cultivar Diversity of Enset (Ensete ventricosum sW.) in Southern Ethiopia. International Journal of Current Research 4, 63-85. 